\title{
“RIDE-HAILING" SERVICES AND MOTOR VEHICLE CRASHES IN PERIPHERAL AREAS OF MADRID, SPAIN
}

\author{
MARÍA FLOR GARCIA ${ }^{1,2}$, ARMANDO ORTUÑO PADILLA ${ }^{1,2}$, \\ BEGOÑA GUIRAOABAD ${ }^{3} \&$ JAIRO CASARES BLANCO \\ ${ }^{1}$ Department of Civil Engineering, University of Alicante, Spain \\ ${ }^{2}$ University Institute of the Water and the Environmental Sciences, University of Alicante, Spain \\ ${ }^{3}$ Department of Civil Engineering, Madrid Polytechnical University, Spain \\ ${ }^{4}$ Civil Engineering, Spain
}

\begin{abstract}
The fast growth of "ride-hailing" platforms such as Uber or Cabify poses important challenges and questions in the cities where they are implemented. According to an official Uber report, in 2018 the company made 14 million trips a day. This new offer of services could improve the supply to segments of demand that previously had greater difficulties in accessing taxis or public transport, for example, young people who moving for leisure, low-income families or residents in the periphery of the cities. When the number of vehicles is lower, they tend to concentrate in the central areas, leaving relatively more remote areas without efficient service. This paper, with a novel approach, has an objective to analyze the impact of ride-hailing platforms on traffic accidents with at least one dead or seriously injured person in the Madrid municipality from 2014 to 2018 and seeing whether, since their arrival, the most vulnerable districts have reduced traffic accidents with young drivers who had consumed alcohol. For it, a regression analysis has been carried out using a Random-Effects Negative Binomial Regression (RENB). The results of the model show that Uber and Cabify services are related to reducing urban accidents. Moreover, in the case of the most vulnerable districts, accidentality with young people and presence of alcohol has also been reduced.
\end{abstract}

Keywords: ride-hailing, drunk driving, traffic fatalities, young drivers, Uber, Cabify, vulnerability.

\section{INTRODUCTION}

Traffic fatalities are one of the leading causes of death in children and young people, aged between 5 and 29, in the world. Every 30 seconds a person dies from a traffic accident, that is, around 1.35 million people a year. Globally, more than $90 \%$ of fatal crashes occur in low-income and middle-income countries (LMIC). Even in high-income countries, people of lower socioeconomic status are most at risk of being involved in these types of accidents [1]. Alcohol use is a leading risk factor in low-income countries, where alcohol has been detected in 33-69\% of fatally injured drivers [2], [3]. In Spain, more than $43 \%$ of young, killed drivers in 2018 tested positive for alcohol, drugs or psychotropic drugs [4].

The entry into service of "ride-hailing" platforms, such as Uber, than operates in more to 630 cities in 80 countries of the world [5], or Cabify, present in 11 countries and more than 90 cities in the world [6], can improve supply in demand segments that previously had greater difficulties in accessing the taxi and reducing deaths and injuries caused by driving under the influence of alcohol.

The investigations carried out in cities where this type of service operates have provided diverse results in terms of their effects. A report by MADD (Mothers Against Drunk Driving) shows that this type of services offers positive results in terms of road safety: young people prefer to use this service as a designated driver instead of trying to drive themselves home after they had too much to drink. The study results are also supported by other data: after UberX launched in cities across California, monthly alcohol-related crashes decreased by $6.5 \%$ among drivers under 30 [7]. 
Leaning on the World Health Organization (WHO), which states that vulnerable areas are more likely to traffic fatalities from alcohol intake [2] and research showing that this type of service offers positive results in terms of road safety, this study will briefly analyze whether there is any relationship between the social characteristics of the different districts of Madrid and traffic accidents with at least one dead or seriously injured person with young drivers who had ingested alcohol.

\section{METHODOLOGY}

\subsection{Traffic accidents data collection}

Firstly, it has been contacted with Statistical Service of the Directorate-General for Traffic of Spain [8], to request them the registration of accidents of the Madrid municipality. This registration has information of accident type, location, vehicles involved, date, hour, victims, etc. The classification of the severity of injuries has been made using the methodology of the Directorate-General for Traffic of Spain, stating that a person involved in a road accident that requires hospitalization for more than 24 hours is classified as a seriously injured person/victim with a serious injury, while a crash victim that requires only emergency assistance or hospitalization for less than 24 hours is classified a slightly injured victim [9].

To continue, the Madrid municipality is divided into the 21 districts which comprise it (Fig. 1). This procedure enables a comparison of diverse urban zones or areas to be made, each of them with different urban or socio-economic parameters. Therefore, the geospatial unit of analysis is the district, not the individual street or crash location [10].

For classifying the traffic accidents for district, it has been necessary to trace accident by accident to know the street, road, avenue or promenade where the accident occurred, and with the help to the Official Madrid Street Map [11], locate the accident in its corresponding district.

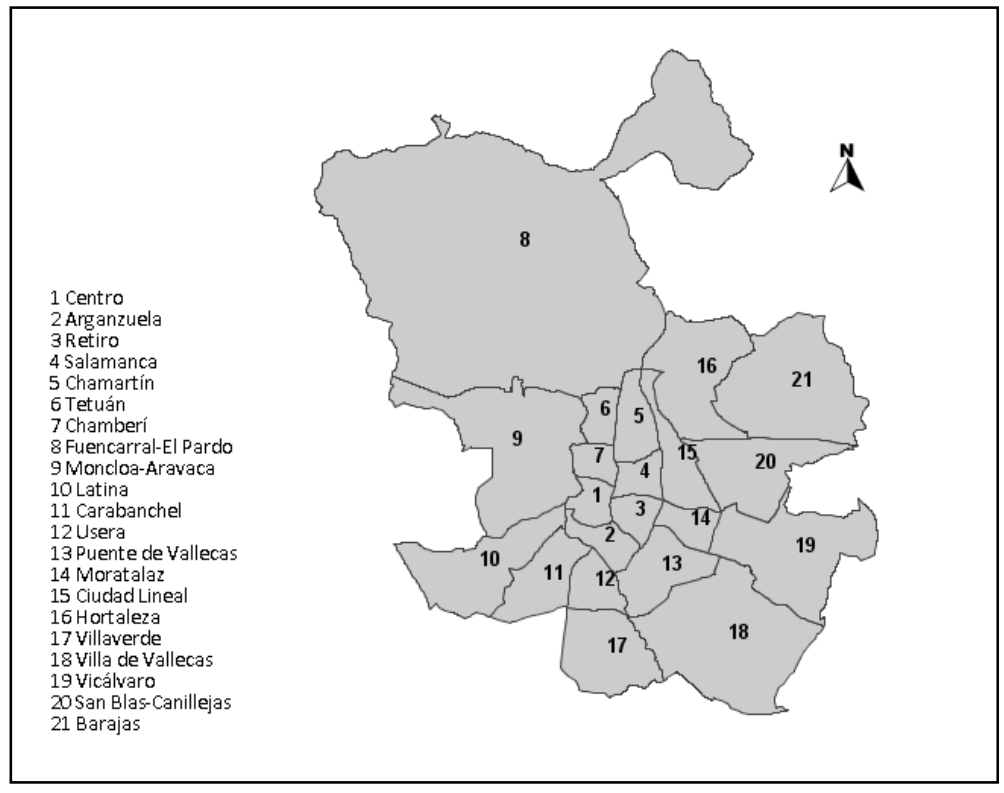

Figure 1: Map of the 21 districts of Madrid. (Source: Own research.) 
After geolocating all the accidents, the dependent variable for each of the 21 districts of Madrid will be the following:

- Traffic accidents with at least one person dead or seriously injured with young drivers who had ingested alcohol

The age range for young drivers covers from 16 years, in the case of involved moped accidents, up to 35 years. According to the report "Nightlife: an exclusively Spanish rite?", young Spanish people from 16 to 29 have more leisure time, which invites them to go out more at night [12]. In this paper, the age has been extended to 35 years, because from 31 years of age young people prefer quieter plans such as going out for lunch or dinner [13], and in these cases they can also consume alcohol.

\subsubsection{Modelling urban traffic accidents}

To analyze accident frequency data, it is very common to apply the Poisson regression model [10], but these models can present over-dispersion. This is one remarkable characteristic of crash-frequency data: the variance exceeds the mean of the crash counts, in these cases it is advisable to resort to the Negative Binomial Regression [14]. In this study, the accident data presented over-dispersion, therefore the Poisson regression model was discarded (Table 1).

Table 1: Mean and variance of accidents with at least one person dead or seriously injured involving young drivers who had ingested alcohol. (Source: Own research.)

\begin{tabular}{ccccc}
\hline Variable & Obs. & Standard deviation & Mean & Variance \\
\hline Traffic Accidents & 105 & 1.551 & 1.743 & 2.404 \\
\hline
\end{tabular}

For the present study, the accidents produced in the 21 districts of Madrid municipality for five years (2014-2018) have been compiled. These data collect a temporal evolution and the best way to model this data is by considering as cross-sectional panel data structure, whose adapted model is known as Random-Effects [15].

Shankar et al. [16] have identified the Random Effects Negative Binomial (RENB) model as more appropriate for modelling median crossover crash frequencies in relation to geometric and traffic variables in Washington State. Thus, the Random Effects Negative Binomial (RENB) model has considered for this study which incorporates a random location specific effects into the relationship between the expected numbers of crashes and the covariates.

The structure of the RENB model used in this study is as follows:

$$
E\left(A_{i t}\right)=\exp \left(\beta X_{i t}+u_{i}+\varepsilon_{i t}\right)
$$

where $\mathrm{E}\left(\mathrm{A}_{\mathrm{it}}\right)$ represents predicted number of fatal or serious crashes in each district $i$ in year $t, \mathrm{X}_{\mathrm{it}}$ the vector of explanatory variables, $\beta$ is the vector of estimable parameter, $\varepsilon_{i t}$ is the vector of residual errors, and $u_{i}$ represents the random effects for $i^{t h}$ location group and exp $\left(u_{i}\right)$ is gamma distributed with mean 1 and variance $a_{i}$, where $a_{i}$ is the over-dispersion parameter in the Negative Binominal model [17].

\subsubsection{Variables analysis}

Uber arrived in Madrid in September 2014 with its UberPop version. It allowed that any adult person with a driving license register as a driver on the platform and perform transport services at the request of users. This service was operative until December 2014. Uber resumed its services in Spain in March 2016, adapting its model to current legislation. 
From that date, Uber employs professional drivers (self-employed person or company) with a VTC licence. Meanwhile, Cabify, the main competitor in Spain of Uber, has been operating in Madrid from 2011.

Although the logical thing would have been to take years prior to 2014 for this analysis, for the presence of Cabify in Madrid, but 2016 has been considered the first year with the presence of these services in the city of Madrid, for the following reason; the National Commission of Markets and Competition claims that during the period from January 2000 to September 2015, an investment in initiatives related to the collaborative economy of $\$ 25,972$ million was recorded worldwide. But this evolution was especially notable in the last two year, increasing from 1,820 million dollars in 2013 to 12,890 in 2015, of which, $62 \%$ went to transportation [18].

This paper mainly analyzes whether Uber and Cabify have helped to reduced the traffic accident with young people and alcohol in the most vulnerability districts. For it, a variable has been included to identify those districts with certain conditions of risk, fragility and disadvantage that make it possible to enter a critical situation of disadvantage. This variable has been denominated Social Status eqn (2), and it is a indicator calculate from the average household income in each district, following the methodology indicates in a report produced by the Territorial Coordination and Social Public Cooperation Area of Madrid, for elaboration of the territorial vulnerability index of neighborhoods and districts of Madrid and vulnerability ranking [19]. The values of the average annual income have been extracted from the Urban Indicators (Urban Audit) prepared by the National Statistics Institute (NSI) [20]

where:

$$
\text { Social Status }=\frac{\text { Average income district }}{\sum_{i=1}^{21} \text { Average } \text { income district }_{i}},
$$

$$
\text { Average income district }=1-\left(\frac{\text { Average household income }}{\left.\sum_{i=\text { District } 1 \text { Average household } \text { income }_{i}}^{\text {Distict }}\right)}\right) \text {. }
$$

The Absolute Unemployment Rate has also been taken into account eqn (4), because it is one of the most used variables to relate traffic accidents and social inequalities between areas or territories [21]

$$
\text { Absolute Unemployment Rate }=\frac{\text { Number of unemployed by district }}{\text { Active population by district }} \times 1000 .
$$

Due to the lack of reliable data for the active population at the district level, "the working age population (from 16 to 64 years)" has been considered instead.

The data has been obtained from the public data bank of the Madrid City Council and its annual Statistical Yearbooks [22], [23].

Furthermore, it is interesting to take into account the number of leisure establishments per district, as they can be a focus of attraction for young people. Tables 2 and 3 show a summary of the explanatory variables and their descriptive statistics, respectively.

Table 2: Explanatory variables. (Source: Own research.)

\begin{tabular}{ll}
\hline Explanatory variables & Definition \\
\hline Leisure establishments & $\begin{array}{l}\text { Number of premises dedicated to the catering, leisure and entertainment } \\
\text { activities (data in thousands) }\end{array}$ \\
Ride-hailing & $\begin{array}{l}\text { Factor used to measure the presence of Uber and Cabify in each year } \\
\text { analyzed ( } 0 \text { No, } 1 \text { Yes) } \\
\text { Indicator calculated from the average household income in each district }\end{array}$ \\
\hline Social status & $\begin{array}{l}\text { Ratio of unemployed population by district to working age population (per } \\
\text { thousand) }\end{array}$ \\
\hline
\end{tabular}


Table 3: Descriptive Statistics. (Source: Own research.)

\begin{tabular}{lccccc}
\hline \multicolumn{1}{c}{ Explanatory variables } & Obs. & Maximum & Minimum & $\begin{array}{c}\text { Standard } \\
\text { deviation }\end{array}$ & Mean \\
\hline Leisure establishments & 105 & 3.097 & 0.029 & 0.587 & 0.804 \\
Ride-hailing & 105 & 1 & 0 & 0.492 & 0.6 \\
Social status & 105 & 0.485 & 0.461 & 0.001 & 0.048 \\
Absolute unemployment rate & 105 & 36.341 & 2.723 & 7.283 & 13.988 \\
\hline
\end{tabular}

3 RESULTS

As previously mentioned, for this analysis, data from 2014 to 2018 were considered. The model is statistically significant as can be seen below in Table 4 . The ride-hailing services variable is statistically significant with a negative coefficient, which shows that the entry of these services has reduced accidents with young people and alcohol, as Meyer [7] and Greenwood and Wattal [24] claimed.

Social Status or vulnerability is significant and with a negative coefficient, which means that since the entry of the Uber and Cabify services, the most vulnerable districts of Madrid have seen reduced accidents with young drivers who had ingested alcohol. It is important to highlight that victims of a serious or fatal accidents do not necessarily have to live in the district where the accident occurred, due to the accident could have occurred when returning home from a party. In the case of unemployment, this variable is significant with a positive coefficient, which shows that accidents increase with the presence of young people and with the number of unemployed, as stated Yusof et al. [25].

Regarding leisure establishments, this variable is significant with a positive coefficient. This means that there is a strong relationship between the agglomerations of leisure establishments (restaurants, pubs, theatres, cinemas...) and a higher concentration of accidents, with serious injuries or deaths with young drivers who have consumed alcohol, in the Madrid municipality.

Table 4: Results of the estimated models. (Source: Own research.)

\begin{tabular}{lc}
\hline \multirow{2}{*}{ Independent variables } & \begin{tabular}{c} 
Dependent variable \\
\cline { 2 - 2 }
\end{tabular} \\
\hline Leisure Establishments & $\begin{array}{c}\text { Traffic Accidents with young people and alcohol } \\
\text { (z-statistics in parentheses) }\end{array}$ \\
Ride-hailing & $0.441^{* *}(2.90)$ \\
Status Social & $-0.382 *(-2.36)$ \\
Absolute Unemployment & $-341.3 *(-1.96)$ \\
Rate & $0.0332 *(2.07)$ \\
Log Likelihood & -167.153 \\
LR chisq & 1.72 \\
Prob $<$ chisq & $0.000^{* * *}$ \\
\hline$* * *$ Significant at 0.001 level; **Significant at 0.01 level; *Significant at 0.05 level.
\end{tabular}




\section{CONCLUSIONS}

The findings presented in this study reveal that the arrival of ride-hailing services in the Madrid municipality is related to the decrease in accidents with seriously injuries or deaths with young drivers who had ingested alcohol. The analysis also shows that these services have had a positive impact in the most vulnerable districts, reducing this type of accident. Furthermore, unemployment, as well as the presence of leisure establishment, increase traffic accidents with young people.

Finally, this study has only considered the traffic accidents with at least one person dead or seriously injured with young drivers who had ingested alcohol. But it is very interesting to analyze what happens with other types of accidents. That is why, at present, this line of investigation continues and it is being analyzed how vulnerability and the presence of Uber and Cabify affect the 21 districts of Madrid, considering as new dependent variables the traffic accidents with at least one person dead or seriously injured:

- Weekends and holidays

- Weekends and holidays with young people

- Weekend and holidays with the presence alcohol or drugs

\section{REFERENCES}

[1] World Health Organization, Global Status Report on Road Safety 2018, Geneva: World Health Organization, 2018.

[2] Peden, M., Scurfield, R. \& Sleet, D., World Report on Road Traffic Injury Prevention, Geneva: World Health Organization, 2004.

[3] Wesson, H.K. et al., Informing road traffic intervention choices in South Africa: The role of economic evaluations. Global Health Action, 9, pp. 30728, 2016.

[4] National Institute of Toxicology and Forensic Sciences. Toxicological Findings in Traffic Accident Fatal Victims 2018, Spain: National Institute of Toxicology and Forensic Sciences. Ministry of Justice, 2018.

[5] Uber, Uber cities across the globe. 2020. https:/www.uber.com/global/es/cities/. Accessed on: 5 May 2020.

[6] Cabify, More security, higher quality and a city within your reach, 2020. https://cabify.com/es. Accessed on: 5 May 2020.

[7] Meyer, J., Uber Possitive: Why Americans Love the Sharing Economy, New York: Encounter Books, 2016.

[8] Directorate-General for Traffic of Spain (Dirección General de Tráfico), Statistical Service, Madrid: Minister for Home Affairs, 2018-2019.

[9] Directorate-General for Traffic of Spain (Dirección General de Tráfico), Statistical Yearbook of Accidents 2016. Madrid: Spanish Ministry for Home Affairs. http://www.dgt.es/Galerias/seguridad-vial/estadisticas-e indicadores/publicaciones/anuario-estadistico-de-accidentes/Anuario-accidentes2016.pdf. Accessed on: 20 Apr. 2020.

[10] Casares, B., Fernández, F. \& Ortuño. A., Built environment and tourism as road safety determinants in Benidorm (Spain). European Planning Studies, 27(7), pp. 1314-1328, 2019. DOI: 10.1080/09654313.2019.1579784.

[11] Area of Government of Sustainable Urban Development, Official Street Map, 2015. Madrid: Madrid City Council. www.madrid.es/UnidadesDescentralizadas/ UDCMedios/noticias/2016/04Abril/28Jueves/Notasprensa/CallejeroOficial/ficheros/ CALLEJERO\%202015.pdf. Accessed on: 18 Feb. 2020. 
[12] Berthet, M.A. et al., The night march: an exclusively Spanish rite? Spain: Reina Sofía Center on Adolescence and Youth. Aid Foundation Against Drug Addiction (Fundación de Ayudad contra la Drogadicción). https://dialnet.unirioja.es/servlet/ libro? codigo $=699885$. Accessed on: 1 May 2019.

[13] Currys PC World, This is the age you're officially 'too old' to go to a nightclub. Yorkshire Evening Post; 10th July 2017. https://www.yorkshireeveningpost.co.uk/ news/age-youre-officially-too-old-go-nightclub-823439. Accessed on: 1 May 2019.

[14] Paternoster, R. \& Brame, R., Multiple routes to delinquency? A test of developmental and general theories of crime. Criminology, 35, pp. 45-84, 1997.

[15] Washington, S.P., Karlaftis, M.G. \& Mannering, F.L., Statistical and Econometric Methods for Transportation Data Analysis, CRC Press, 2010.

[16] Shankar, V.N., Albin, R., Milton, J. \& Mannering, F., Evaluating median crossover likelihoods with clustered accident counts: An empirical inquiry using the random effects negative binomial model, Transportation Research Records: Journal of the Transportation Research Board, 1635(1), pp. 44-48, 1998.

[17] Naznin, F., Currie, G., Logan, D. \& Sarvi, M., Application of a random effects negative binomial model to examinetram-involved crash frequency on route sections in Melbourne, Australia. Accident Analysis and Prevention, 92, 15-21, 2016.

[18] National Commission of Markets and Competition, Study on new service delivery models and the collaborative economy - E/CNMC/004/15, Spain: National Commission of Markets and Competition, 2016.

[19] Madrid City Council, Methodology for the preparation of the territorial vulnerability index of neighborhoods and districts of Madrid and ranking of vulnerability. https://datos.madrid.es/portal/site/egob/menuitem.c05c1f754a33a9fbe4b2e4b284fla5 a0/?vgnextoid=d029ed1e80d38610VgnVCM2000001f4a900aRCRD\&vgnextchannel $=374512 \mathrm{~b} 9 \mathrm{ace} 9 \mathrm{f} 310 \mathrm{VgnVCM} 100000171 \mathrm{f5a} 0 \mathrm{aRCRD} \& v g n e x t f m t=$ default. Accessed on: 1 Apr. 2020.

[20] Madrid City Council, Urban Audit. www.madrid.es/portales/munimadrid/es/Inicio/ElAyuntamiento/Estadistica/Areas-de-informacion-estadistica/Economia/Renta/UrbanAudit/?vgnextfmt=default\&vgnextoid=6d40393c7ee41710 VgnVCM2000001f4a900 aRCRD\&vgnextchannel=ef863636b44b4210VgnVCM2000000c205a0aRCRD. Accessed on: 1 Apr. 2020.

[21] Sánchez, M.P., Tejada, A. \& Escribano, F., Interregional inequality and road accident rates in Spain. Accident Analysis and Prevention, 2020.

DOI: https://doi.org/10.1016/j.aap.2019.105347.

[22] Madrid City Council, Data Bank. www2.munimadrid.es/CSE6/jsps/menu BancoDatos.jsp. Accessed on: 20 Mar. 2020.

[23] Madrid City Council, Statistic Yearbook 2014-2018, Madrid: Madrid City Council, 2014-2018.

[24] Greenwood, B.N. \& Wattal, S., Temple University. Show me the way to go home: An empirical investigation of ride-sharing and alcohol related motor vehicle fatalities. MIS Quarterly, 41, 163-187, 2017.

[25] Yusof, N.B., Hoque, M.A., Steele, M.C., \& Yong, S.Y., Extended investigation on road fatality in Brunei. International Journal of Injury Control and Safety Promotion, 26(1), 2019. DOI: 10.1080/17457300.2018.1476381. 